International Journal of Linguistics, Literature and Culture
Available online at https://sloap.org/journals/index.php/ijllc/
Vol. 7, No. 6, November 2021, pages: 441-458
$\begin{aligned} & \text { ISSN: 2455-8028 } \\ & \text { https://doi.org/10.21744/ijllc.v7n6.1948 }\end{aligned}$

\title{
Holy Bali Scriptures in Usada Bali Traditional Medicine
}

I Made Suweta ${ }^{\text {a }}$

Article history:

Submitted: 27 August 2021

Revised: 09 September 2021

Accepted: 18 October 2021

\section{Keywords:}

Balinese medicine;

Modre script;

rerajahan calligraphy;

Usada Bali;

Wijaksara script;

\begin{abstract}
Based on the study in this paper, several things were found as the results of the study as follows ${ }^{\mathrm{b}}$. The forms of Balinese script used by shamans in traditional Balinese medicine include scripts that are classified as: wijaksara script, modre script, and wresastra/swalalita script with various script equipment as attributes. The functions of Balinese script which are classified as sacred scripts used in traditional Balinese medicine are: as a symbol of God in its various manifestations, as a symbol of the universe, and as a symbol of the human body. The meaning of the Balinese script used in traditional Balinese medicine is: praying to God in various holy powers of God, asking for life energy so that the person being treated can be healthy as before, can absorb magical religious energy so that the medicinal infrastructure used to treat the sick has power religious magical efficacious to treat.
\end{abstract}

International journal of linguistics, literature and culture () 2021. This is an open access article under the CC BY-NC-ND license (https://creativecommons.org/licenses/by-nc-nd/4.0/).

\section{Corresponding author:}

I Made Suweta,

STAHN Mpu Kuturan Singaraja Bali, Indonesia.

Email address: madesuwetabali62@gmail.com

a The author is a Lecturer/Professor of Linguistics (Cultural Linguistics Concentration) at the STAHN Mpu Kuturan Singaraja Bali, Department of literature, Religion, Balinese Language Education, Indonesia

$\mathrm{b}$ This paper is a study of the use of Balinese script by traditional Balinese shamans in carrying out traditional Balinese usada medicine, as well as the author's efforts to preserve Balinese traditional scripts in the Balinese Lontar Usada Manuscript.k09wew 


\section{Introduction}

Not all languages in the world have their spelling system, as well as in Indonesia, not all regional languages in this archipelago have their spelling system. Only a few regional languages in the world have their spelling system, one of which is Balinese (Sujarwo et al., 2015; McCauley, 1988). The Balinese regional language has a spelling tradition called Balinese script used in lontar writing which usually contains: Hinduism, housing design techniques (asta bhumi and asta kosala-kosali), traditional medicine (usada), and so on. This lontar heritage is stored in the Gedung Kirtya (one of the historic scriptoriums in Bali) which is classified into six sections as follows: (1) Vedas, (2) Religion, (3) Wariga, (4) Itihasa, (5) Babad, and (6) tantri (Jendra et al., 1975). So the Balinese language has two writing systems, namely Balinese writing with Latin script and Balinese writing with Balinese script. With the Balinese writing tradition with the Balinese script, Balinese is considered a major regional language, because, in addition to the Balinese language having an oral tradition, the Balinese language also has its written tradition called Balinese script (Foley, 1997). Other regional languages in Indonesia which also have their writing traditions are: Javanese, Sundanese, Bugis, Sasak, and so on. Especially for the Balinese regional language, because as a large regional language, it has a tradition of writing Balinese script, it needs to be preserved and developed so that it is more efficient in people's lives, its language and literature can be utilized in building a community of character (Duranti, 2011).

In particular, the discussion in Balinese script used in the traditional Balinese medicine system, it is clear that this script is associated with symbols of human nature as the microcosm (buana alit), the universe as the macrocosm (buana agung), the gods as manifestations of God, the vibrations of spiritual energy, which is used by the Balinese usada healer to ask God to successfully heal the sick he treats (Palmer, 1996). In this paper, we will only discuss the Balinese script used by shamans who are classified as Balinese usada healers who are classified as balian penengen (white magic) to heal sick people to be healthy, we will not discuss shamans who make healthy people sick, which in Balinese society is known as balian pangiwa (black magic). In particular, about balian pangiwa, has been widely reviewed by Kardji (1999).

About the Balinese script used in traditional Balinese medicine (usada), in general, the Balinese script is classified into two, namely: (1) the common Balinese script/ordinary Balinese script (including wreastra and swalalita) and (2) Balinese script which is classified as a traditional Balinese script sacred (including wijaksara script and modre script) (Nala, 2006). All these characters can be emphasized as follows:

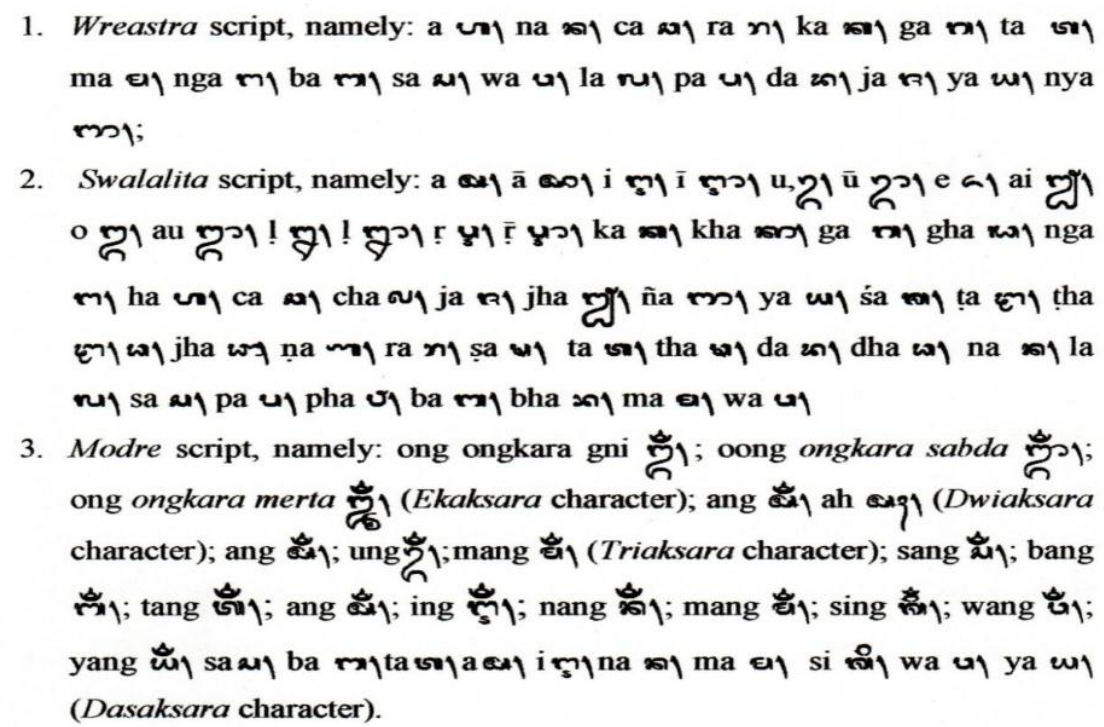

Balinese script used in traditional Balinese medicine is included in the classification of the sacred script (Sujarwo et al., 2016; Alonso-Castro et al., 2012). This sacred script is not only used in the traditional Balinese medicine system, it is also used in Hindu religious rituals in religious ceremonies called the Panca Yadnya ceremony. This sacred script can be divided into two types, namely: (1) wijaksara script and (2) modre script. The wijaksara script is a wresastra/swalalita script that is given as a complement to ulu candra and ulu ricem. Unlike the modre script, which 
is not all easy to read, because they are attached to the image or blends with the rerajahan, it will be explained as follows.

Based on the narrative in the introduction above, there are three problems to be discussed, namely: (1) what is the shape of the Balinese script in usada Balinese traditional medicine?, (2) what is the function of the Balinese script in usada Balinese traditional medicine?, and (3) what is the meaning of the Balinese script in usada Balinese traditional medicine?

\section{Results and Discussions}

\subsection{Balinese script forms in usada Balinese traditional medicine}

The Balinese script used in traditional Balinese medicine is called the sacred script. In the manuscript of lontar usada there are several types of Balinese script. This can be seen in several types lontar usada manuscripts such as: Bodha Kecapi, Cukil Daki, Gering Agung, Kalimosada, Ratuning Usada, and other types of lontar usada (Pulasari, 2009; Team UPTD B POT KOM Bali Provincial Health Office, 2008). Three types of Balinese script exist in traditional Balinese medicine: (1) wijaksara script, (2) modre script, and (3) Wresastra/Swalalita script with attributes attached to the sacred script. The three types of the sacred script will be explained in the following explanation.

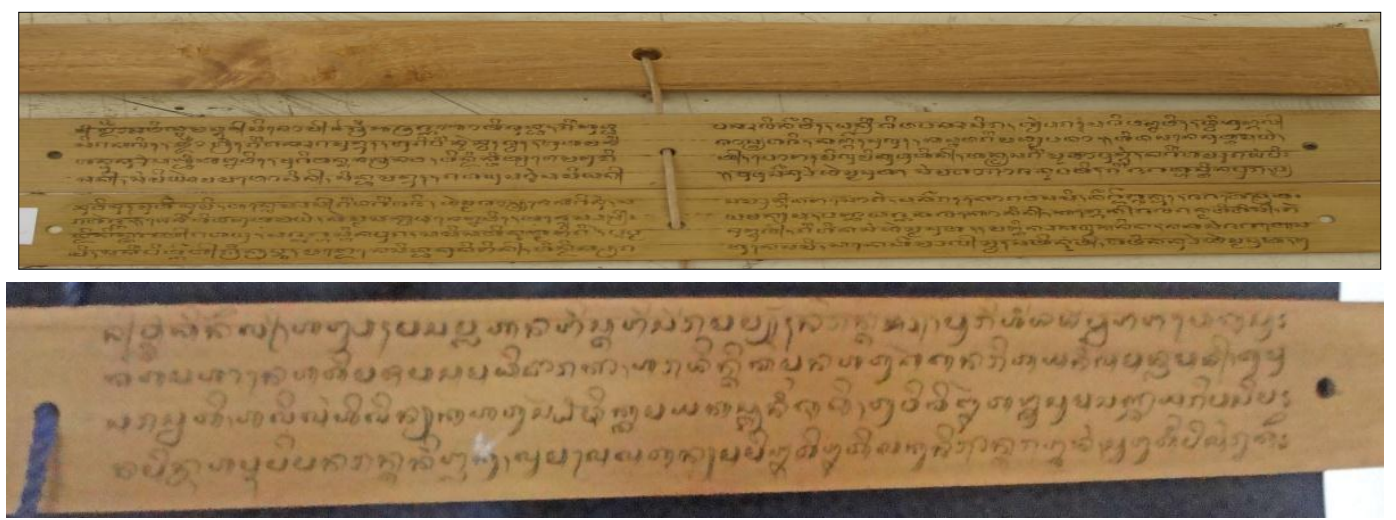

Figure 1. Balinese Script in the Manuscript of Lontar Usada 


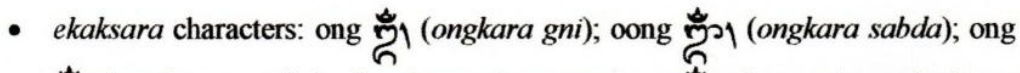

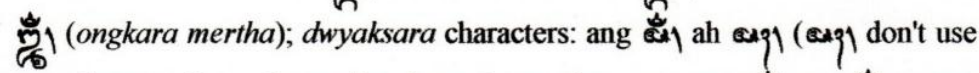

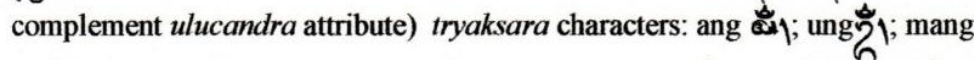

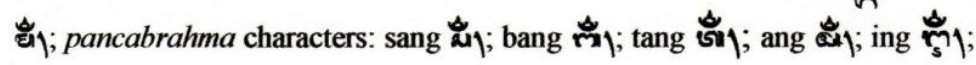

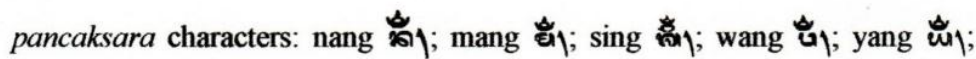

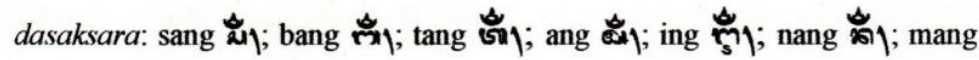

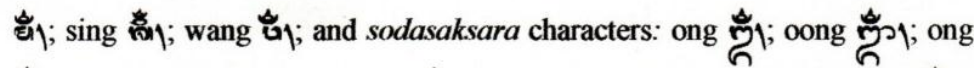

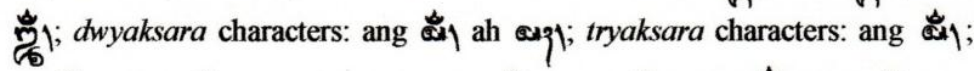

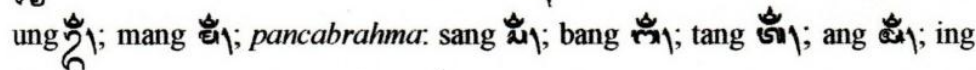

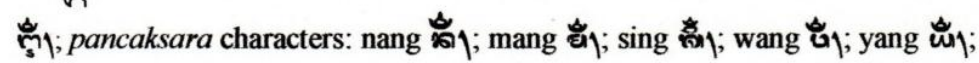

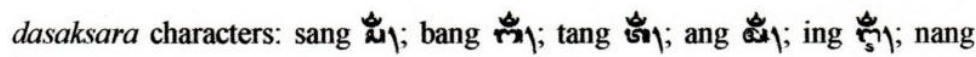

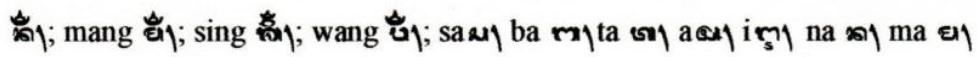

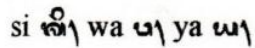

\section{Wijaksara Script/Bijaksara Script}

The wijaksara/bijaksara script includes the classification of sacred scripts, namely scripts that are generally used in Hindu religious ritual activities (Panca Yadnya), Balinese usada, asta bhumi, asta kosala-kosali, and other magical activities, as religious magical symbols, symbols of God in various ways. its manifestations (Soken Bandana (in Suastika, 2005); some are in the form of complementary attributes of the Ulucandra script, some do not use the complement of the Ulucandra attribute sacred script, such as:

The last ten sacred scripts are not complemented by the ulu candra sound script but are also included in the dasaksara wijaksara script group (Yudhiantara, 2003). Scripts belonging to the Wijaksara script group are generally easy to read even though they have been combined with calligraphy/rerajahan images (Lindeman \& Aarnio, 2007; Unterrainer et al., 2011). Below will be explained some data on rerajahan calligraphy images that are included in the wijaksara script group as contained in the Lontar Usada (Usada Kuranta Bolong: Diskes Prov. Bali, 2008; Usada Ceraken Tingkeb: Diskes Prov. Bali, 2008; Usada Sasah Bebai, Diskes of the Province of Bali, 2008; Usada Edan: Diskes of the Province of Bali, 2008), which are used by traditional Balinese traditional healers in their activities to treat the sick, as shown in the following data:

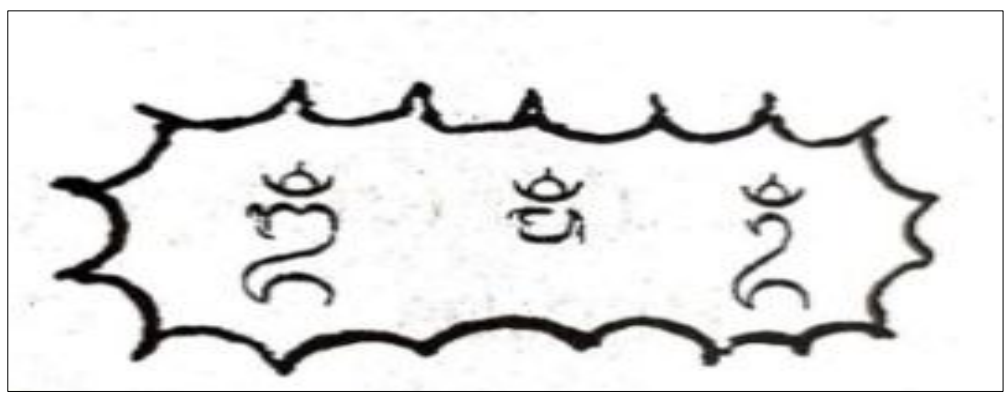

Figure 2. Usada Tiwas Punggung (Nala, 2006) 


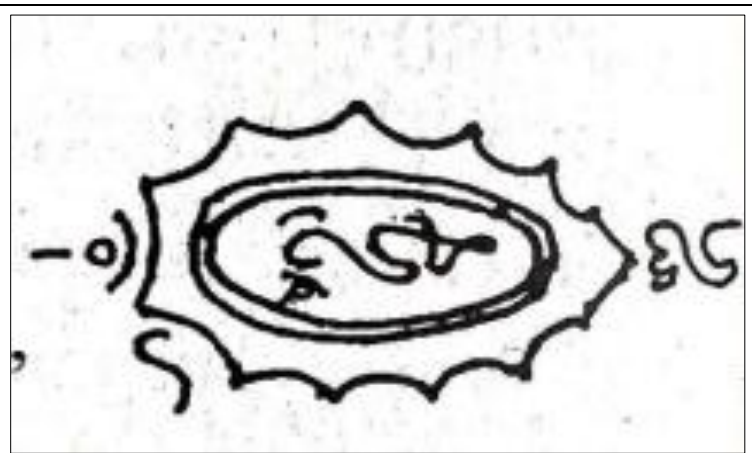

Figure 3. Usada Tiwas Punggung (Nala, 2006)

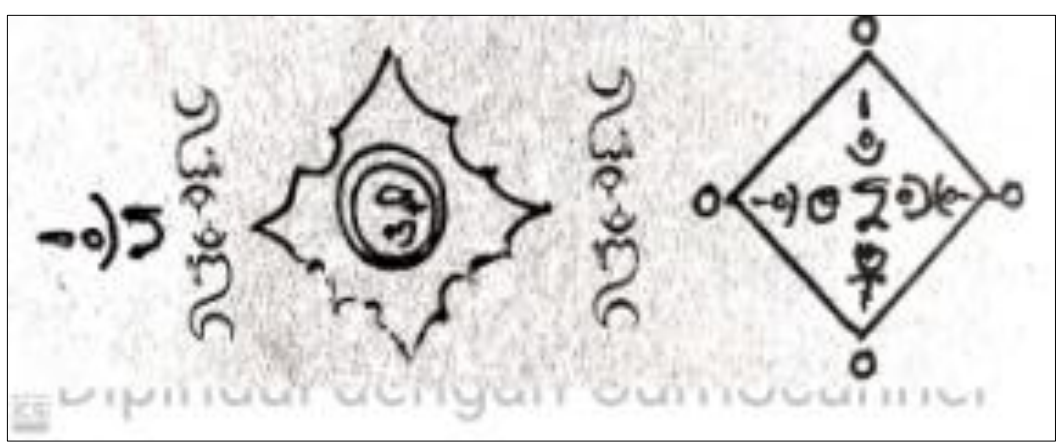

Figure 4. Usada Tiwas Punggung (Nala, 2006)

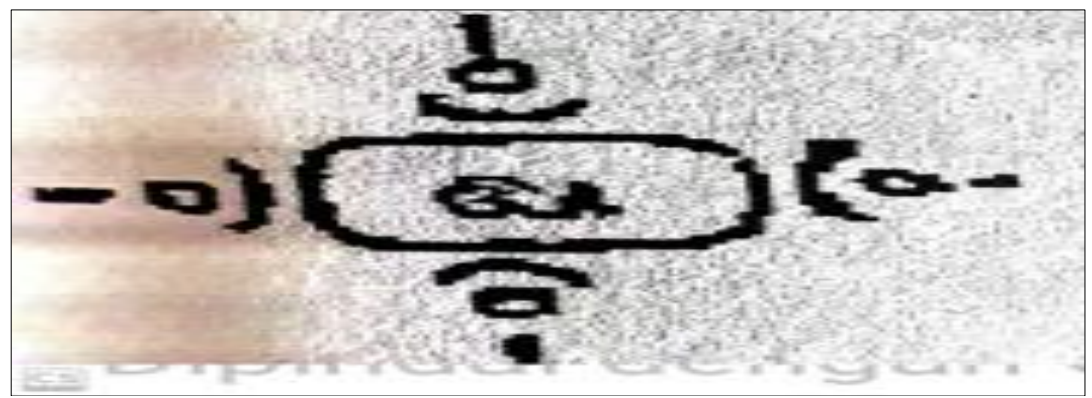

Figure 5. Usada Tiwas Punggung (Nala, 2006)

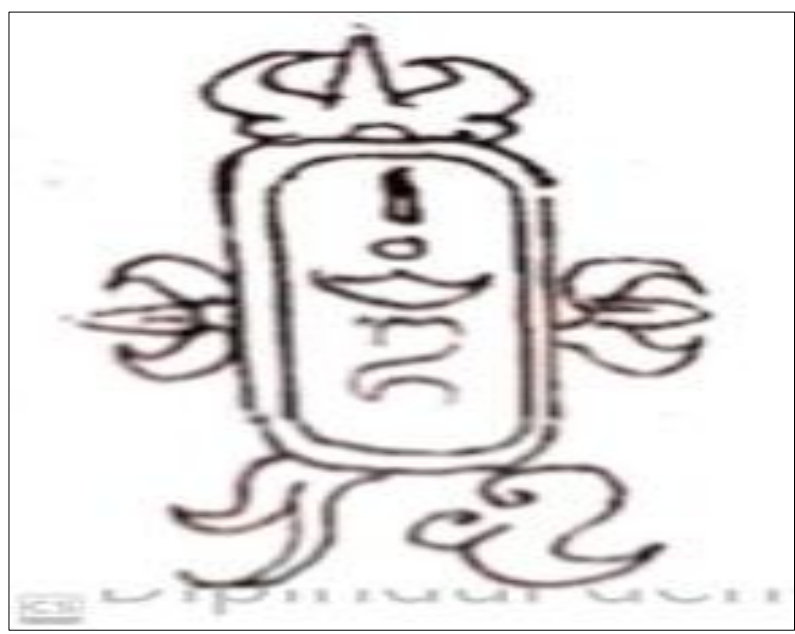

Figure 6. Usada Tiwas Punggung (Nala, 2006)

Suweta, I. M. (2021). Holy Bali scriptures in usada Bali traditional medicine. International Journal of Linguistics, Literature and Culture, 7(6), 441-458. https://doi.org/10.21744/ijllc.v7n6.1948 


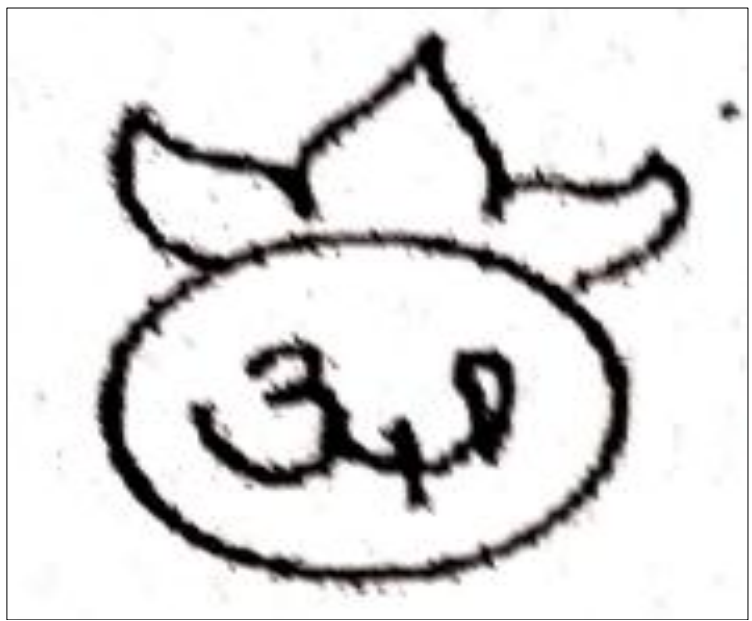

Figure 7. Usada Pangeraksa Jiwa (UPTD Diskes Prov. Bali, 2008)

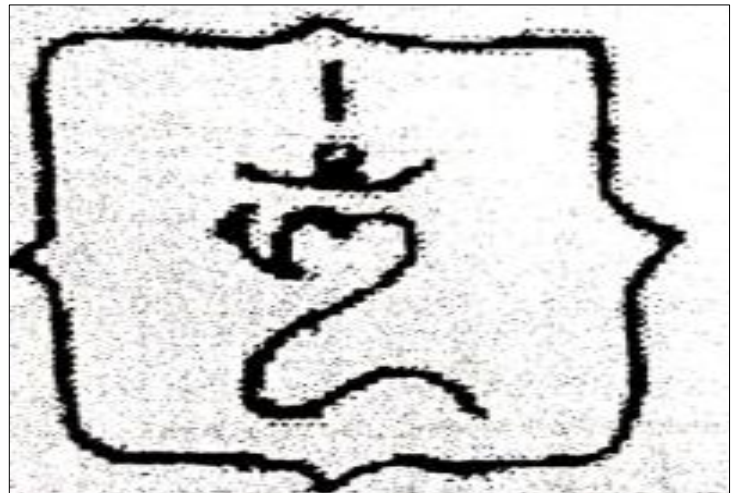

Figure 8. Usada Kuranta Bolong (UPTD Diskes Prov. Bali, 2008)

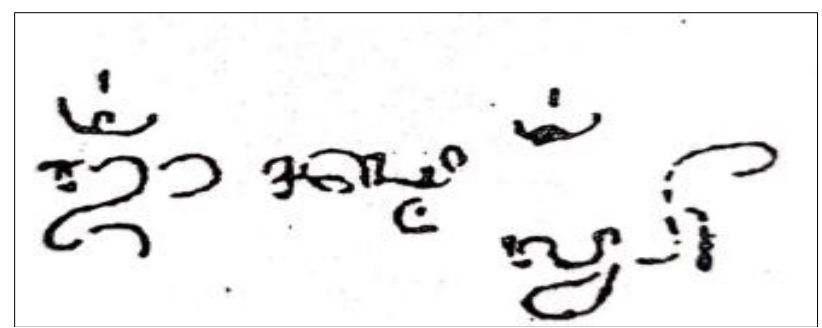

Figure 9. Usada Tuju (Pulasari, 2009)

\section{Modre Script}

Modre script is also included in the sacred script group, some of which is included in the modre script is a script that is generally the same as the wijaksara script, but is more difficult to read, not all of them can be read, moreover, some are completely unreadable, because the script blends with the calligraphy image of rerajahan; to be able to read modre script, it is better to be assisted by reading lontar krakah modre aji griguh a kind of dictionary book to read modre characters that are integrated with rerajahan calligraphy images (Preston \& Epley, 2009; Foley, 2011). Rerajahan calligraphy images made by traditional Balinese healers can be shown as examples in the following pictures, quoted from Nala (2006), as follows: 

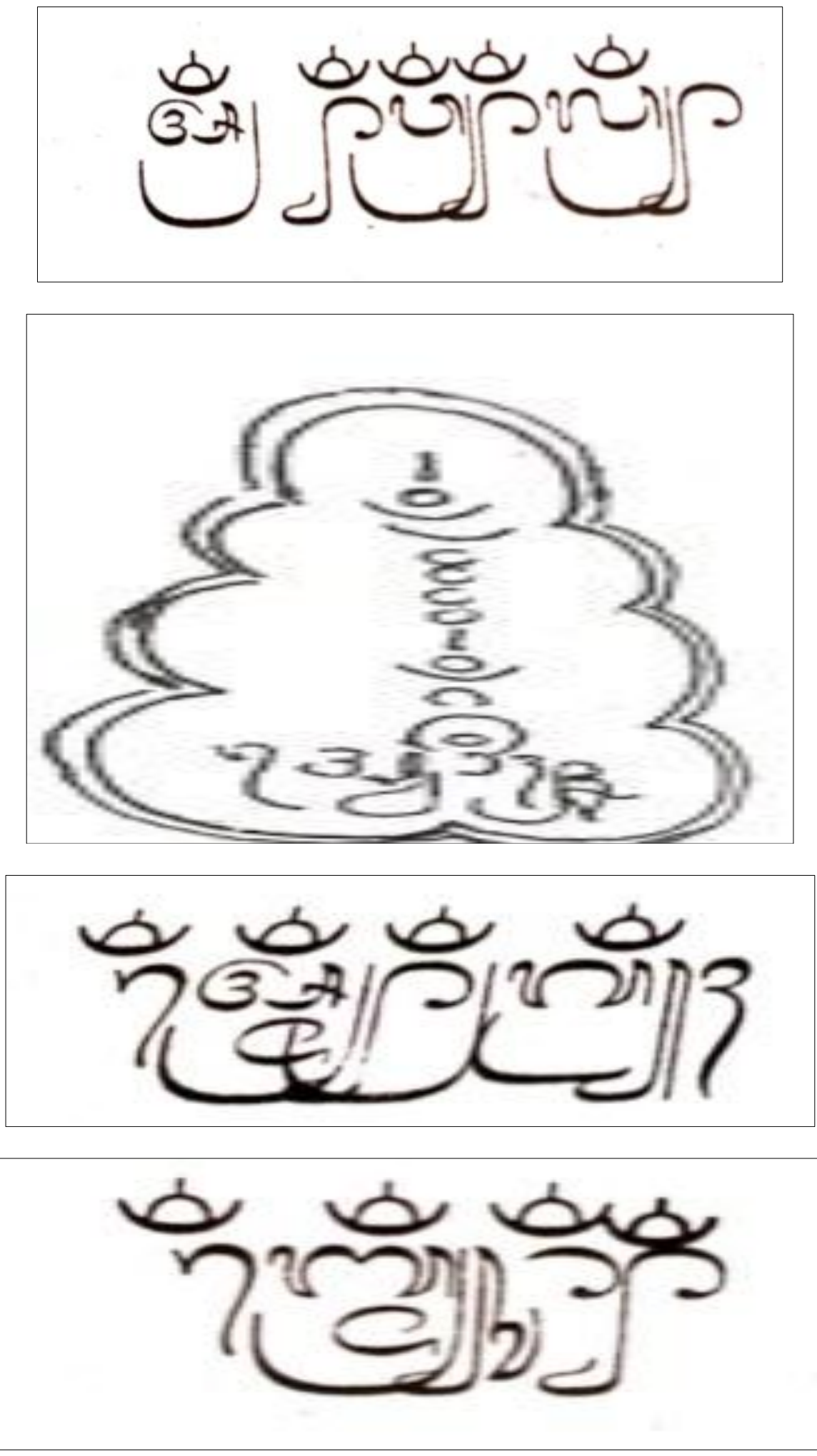

Suweta, I. M. (2021). Holy Bali scriptures in usada Bali traditional medicine. International Journal of Linguistics, Literature and Culture, 7(6), 441-458. https://doi.org/10.21744/ijllc.v7n6.1948 


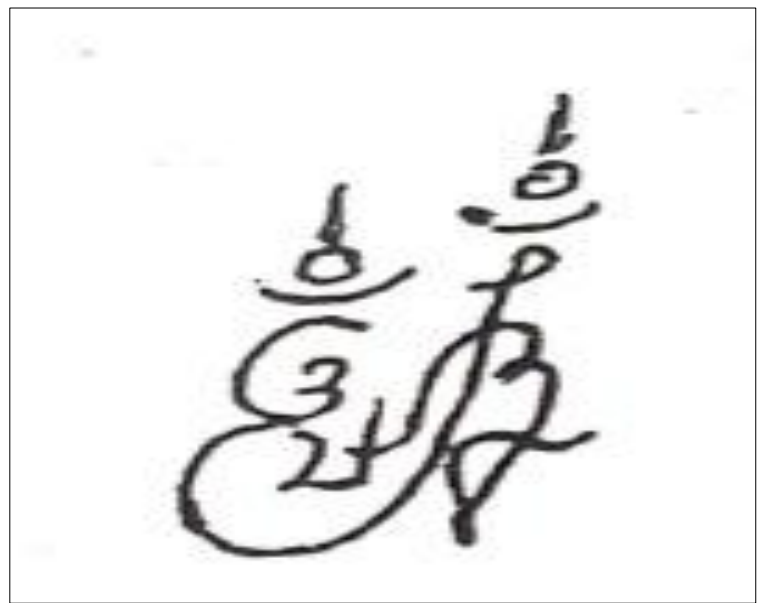

Figure 10. Rerajahan calligraphy images made by traditional Balinese healers

Wresastra/Swalalita Script with Sacred Script Attributes

Not only sacred scripts that are included in the wijaksara and modre script groups, as explained above, there are also some ordinary scripts namely wreastra and swalalita that have been given the attributes of the sacred script, which are commonly used by traditional Balinese healers in their treatment activities. as follows:

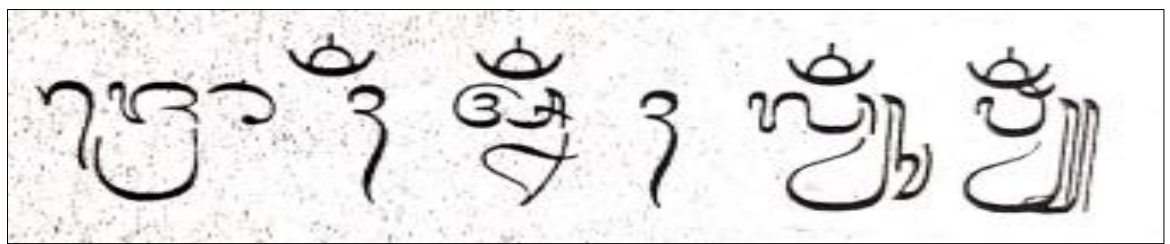

Figure 11. Usada Dalem (Nala, 2006)

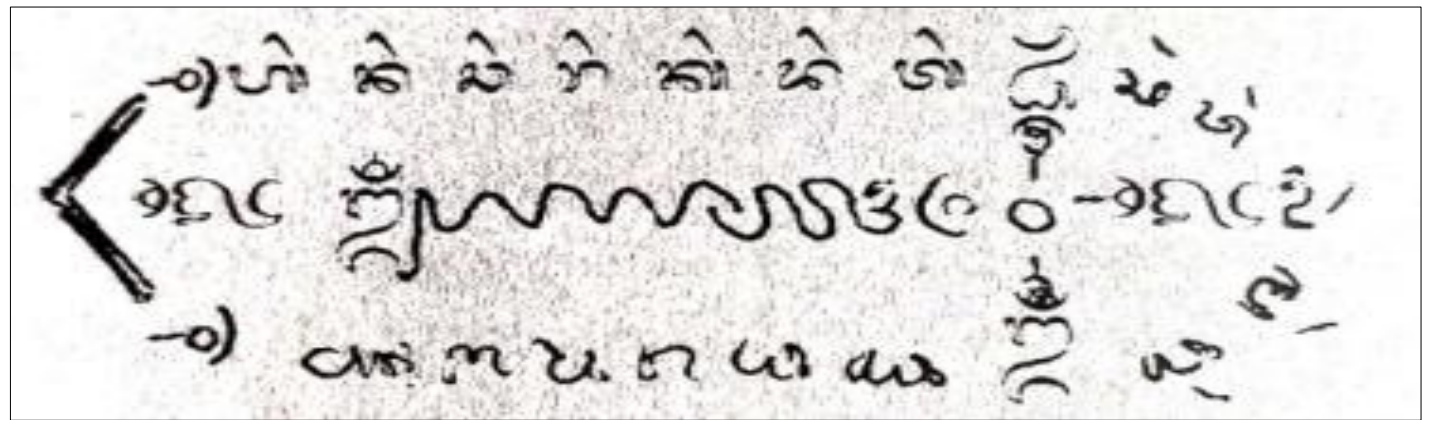

Figure 12. Usada Tiwas Punggung (Nala, 2006)

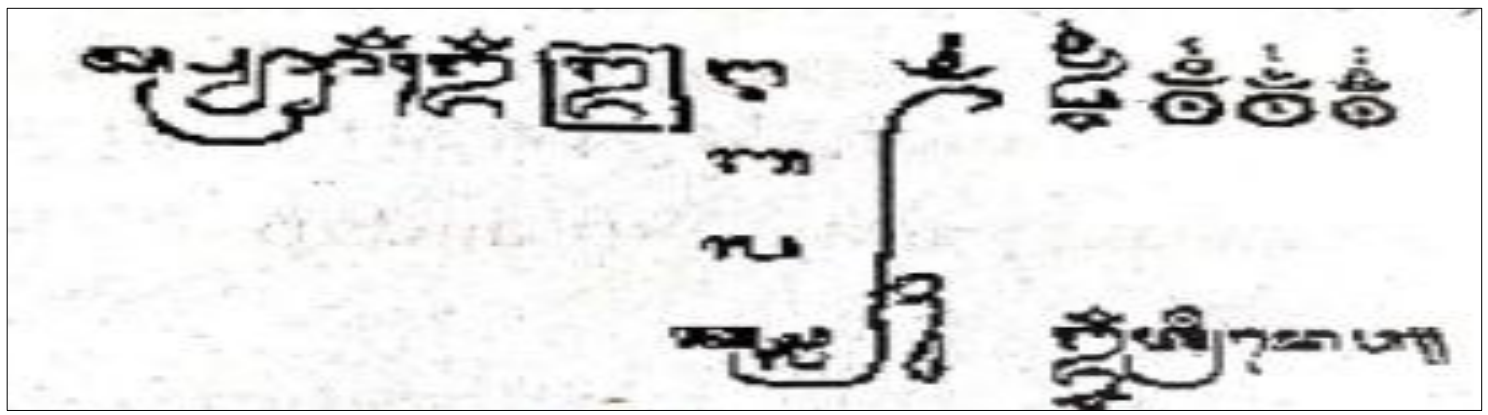

Figure 13. Usada Gering Agung (Nala, 2006) 


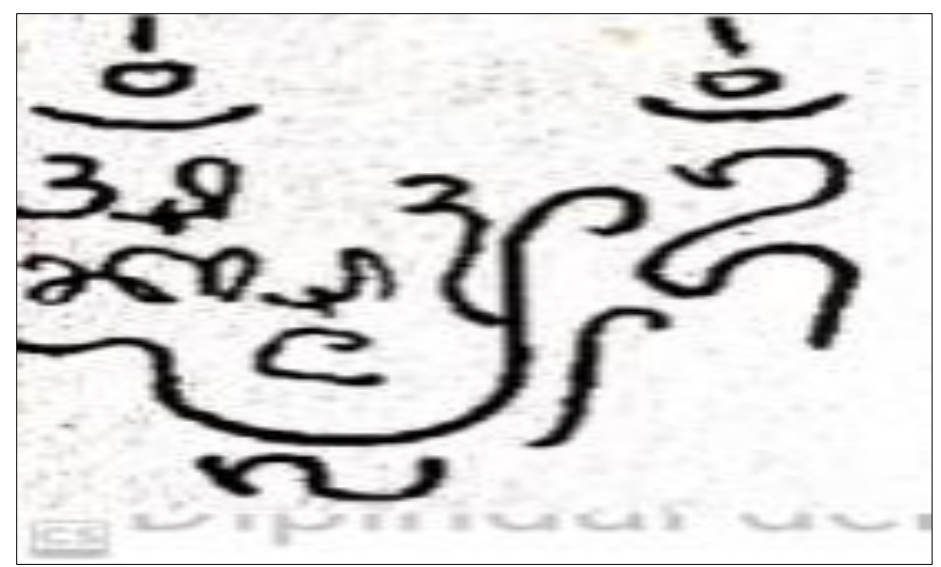

Figure 14. Usada Netra (Nala, 2006)

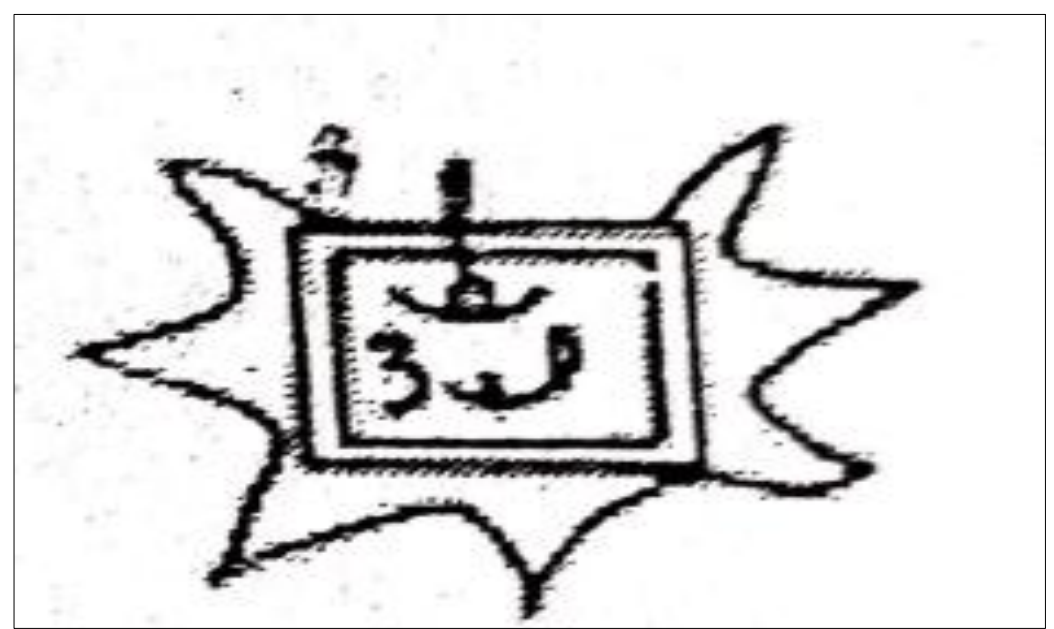

Figure 15. Usada Pangeraksa Jiwa (UPTD Diskes Prov. Bali, 2008)

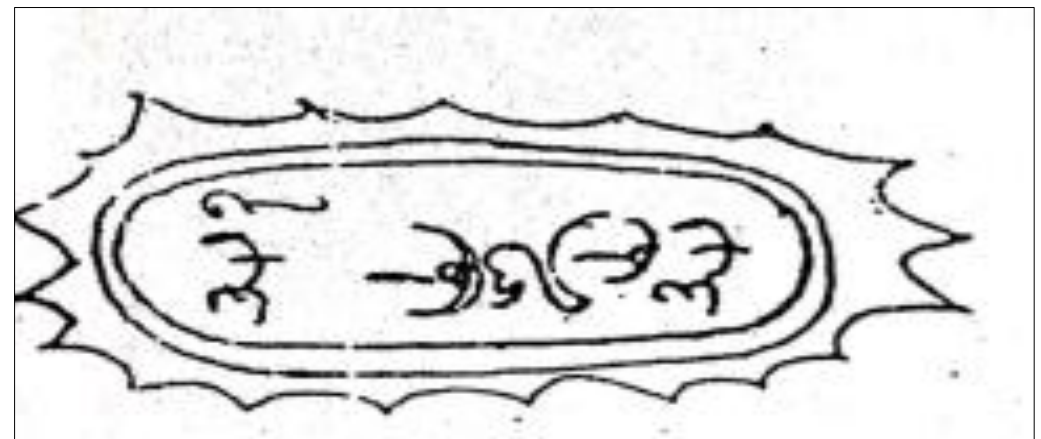

Figure 16. Usada Dalem (Pulasari, 2009) 


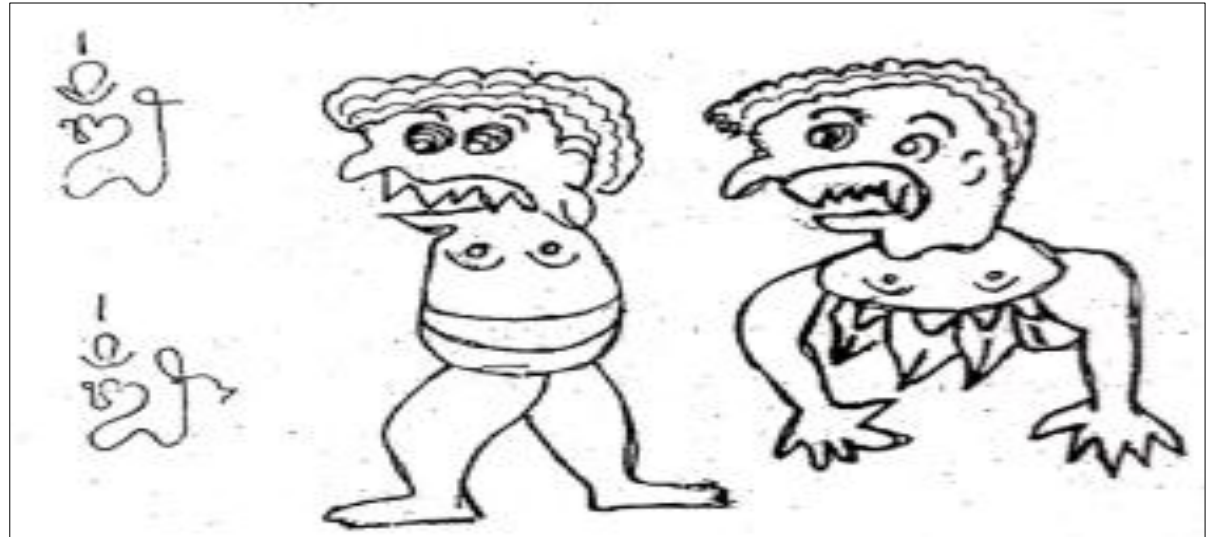

Figure 17. Usada Buduh (Pulasari, 2009)

\subsection{Functions of Balinese script in Usada Balinese traditional medicine}

As a symbol of God in its various manifestations

The Balinese traditional healer, do not make medicines based solely on concoctions from certain ingredients obtained from the natural environment, but also make them by combining spiritually by making rerajahan calligraphy on a piece of cloth media which is written in the sacred script as a symbol of the god as the symbol of the god. Manifestations of God and other sacred symbols (Eves \& Kelly-Hanku, 2020; Williams, 2016). This function is identical to what Supriyanto (in Suastika, 2005) discussed about the mystical function of Javanese script in Javanese medicine. The existence of script as a symbol of God in its various manifestations can be seen in the following types of Balinese script:

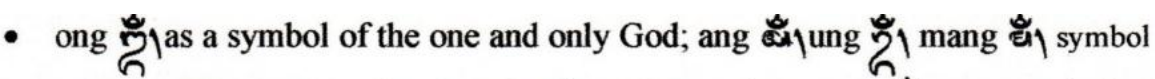
of God as manifestation Trimurti: Brahma, Wismu, Siwa; sang ฌ્ God's manifestation Iswara; bang mั\} \text { as a symbol of God's manifestation } Brahma, tang जัj; as a symbol of God's manifestation Mahadewa; ang 范 as a symbol of God's manifestation Wismi; ing भुगे as a symbol of God's manifestation Parama Siwa, nang ฝั่। as a symbol of God's manifestation

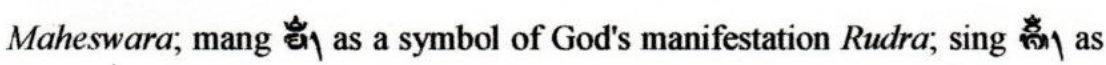
a symbol of God's manifestation Sangkara; wang 岁 as a symbol of God's manifestation Sambu; dan yang $\stackrel{\leftrightarrow}{u}$ as a symbol of God's manifestation Siwa Guru.

The meaning of the function of God in the traditional Balinese medicine system is supported by several data, such as the following rerajahan calligraphy images: 


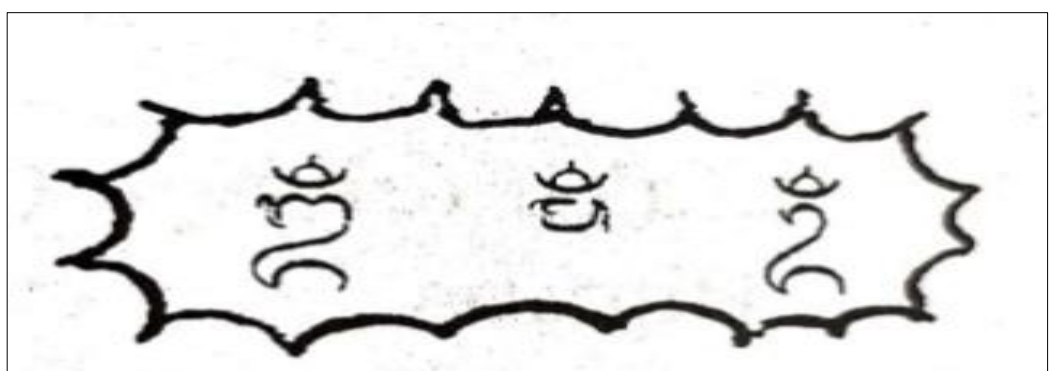

Figure 18. Usada Tiwas Punggung (Nala, 2006)

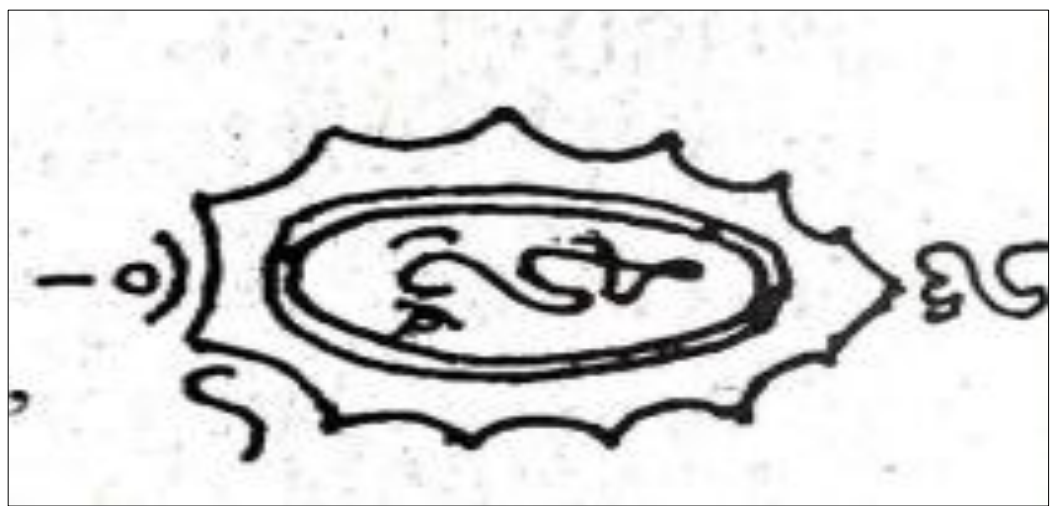

Figure 19. Usada Tiwas Punggung (Nala, 2006)

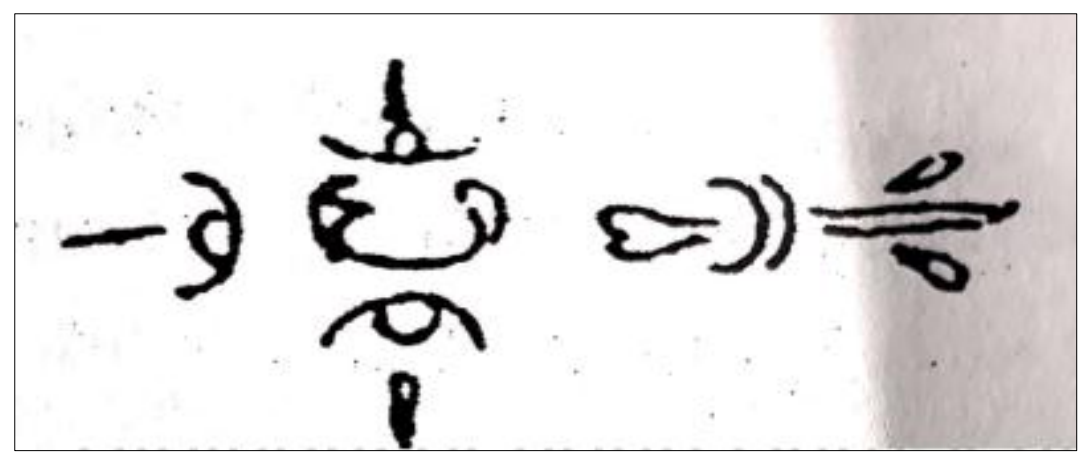

Figure 20. Usada Bhagawan Kasyapa (Pulasari, 2009)

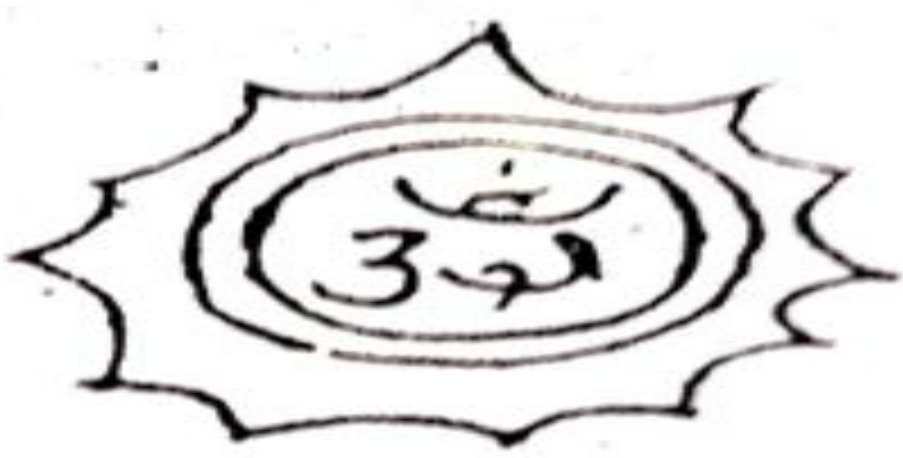

Figure 21. Usadha Dalem (Pulasari, 2009)

Suweta, I. M. (2021). Holy Bali scriptures in usada Bali traditional medicine. International Journal of Linguistics, Literature and Culture, 7(6), 441-458. https://doi.org/10.21744/ijllc.v7n6.1948 


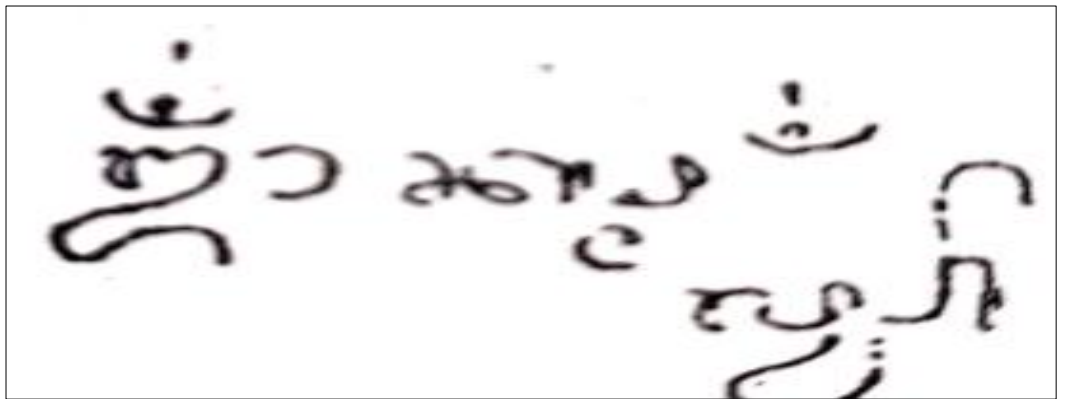

Figure 22. Usada Tuju (Pulasari, 2009)

As a symbol of the universe and the human body

Apart from being a symbol of God as mentioned above, the Balinese script used in traditional Balinese medicine also functions as a symbol of the universe (macrocosm) and the human body (microcosm) (Suryani et al., 2020). To make it clearer, here are some of the Balinese scripts referred to, such as:

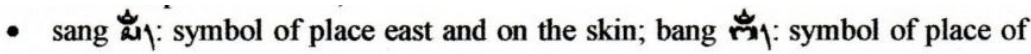

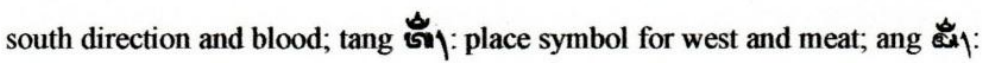

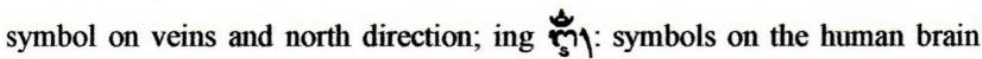
and the upper middle realm; nang ถั๊ the symbol for the place of the southeast direction and the lungs on the human body; mang घूँj: symbol for the place of the southwest direction and on the human gut; sing of the place for the northwest direction and the spleen on the human body; wang $\mathrm{U}_{j}$ : the symbol for the place of the northeast direction and the esophagus on the human body; yang $\stackrel{\leftrightarrow}{\rfloor}$ symbol for the lower center and a series of hearts on the human body (in Pulasari, 2009:239-299).

The relationship between the Balinese script and the source of the Balinese lontar usada script, for more details, here are some examples of rerajahan lontar usada calligraphy accompanied by a table of the relationship between the Balinese script and the universe (macrocosm) and the human body (microcosm) as follows:

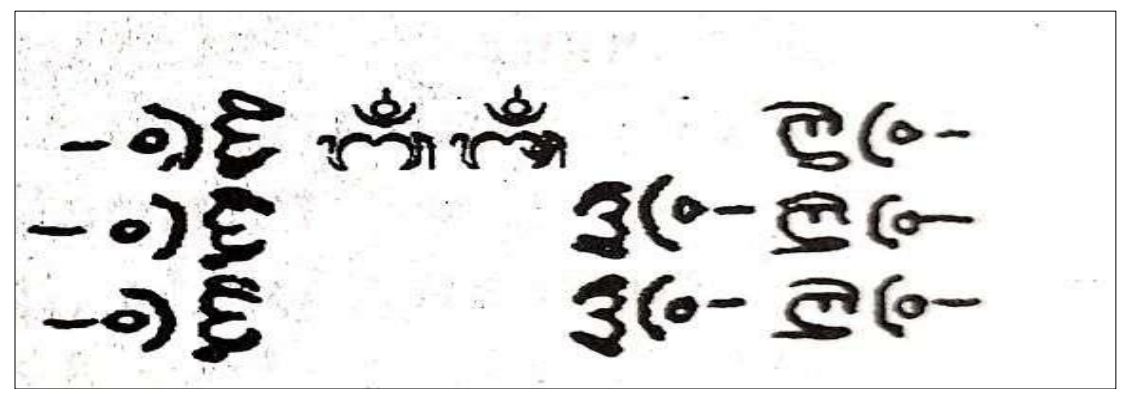

Figure 23. Usada Tiwas Punggung (Nala, 2006) 


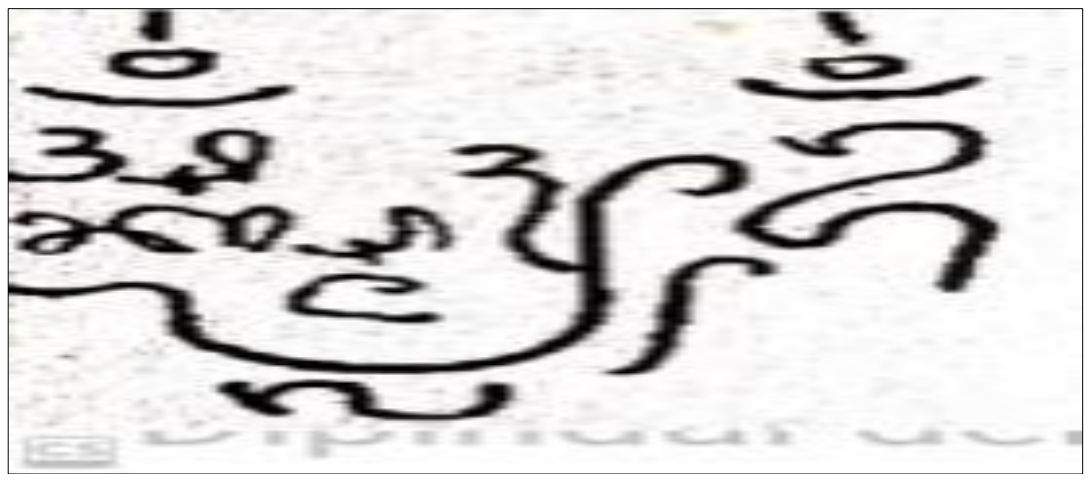

Figure 24. Usada Netra (Nala, 2006)

Table 1

Balinese Script Relating to the Universe and the Human Body

\begin{tabular}{|c|c|c|c|c|c|c|c|}
\hline \multirow{2}{*}{ No } & \multirow{2}{*}{$\begin{array}{c}\text { God's } \\
\text { Manifestation }\end{array}$} & \multirow{2}{*}{ Color } & \multirow{2}{*}{ Weapon } & \multicolumn{2}{|c|}{ Script } & \multicolumn{2}{|c|}{ The place } \\
\hline & & & & voice & letter & Earth & Organs \\
\hline 1 & Iswara & white & Bajra & Sang & S, & East & Heart \\
\hline 2 & Brahma & red & Gada & Bang & b, & South & Heart \\
\hline 3 & Mahadewa & yellow & Nagapasah & Tang & $t_{s}$ & West & Ungsilan \\
\hline 4 & Wisnu & black & Cakra & Ang & Á, & North & Bile \\
\hline 5 & Siwa & Cry & Padma & Ing & $\div$ & Middle Down & Mid Heart \\
\hline 6 & Maheswara & dice & Dupa & Nang & $\mathrm{n}$ & southeast & Lungs \\
\hline 7 & Rudra & orange & Muksala & Mang & $\mathrm{m}$ & Southwest & Intestines \\
\hline 8 & Sangkara & green & Angkusa & Çing & 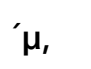 & Northwest & Spleen \\
\hline 9 & Sambu & Blue & Trisula & Wang & $w_{\text {s }}$ & Northeast & Anus \\
\hline 10 & Siwa Guru & colorful & Padma & Yang & $y$, & Upper Middle & Heart Arrangement \\
\hline
\end{tabular}

Source: (Nala, 2006)

\subsection{The meaning of Balinese traditional medicine Usada Bali}

\section{Praying to God in its various manifestations}

The shamans who carry out traditional Balinese usada medicine do not only use ingredients derived from various plants and mix them into medicines, but in their medical activities, they always pray to God so that in treating a person they can be healed with God's help (Halliday \& Hasan, 1989). Even traditional Balinese healers are worried that they will not be able to heal people who are being treated without God's help. This is what causes traditional Balinese healers to always make calligraphy with sacred Balinese script with symbols of God as a manifestation of 
God, as a means of praying for God's mercy to help heal the person being treated. The Balinese script, which is meant as the prayer of the traditional Balinese healers, can be seen as follows:

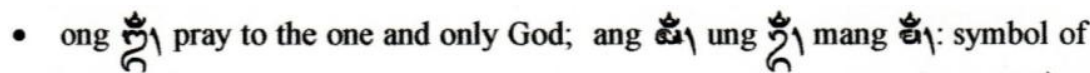
worshiping God in its function as Tri Murti: Brahma, Wismu, Siwa, sang \&ّل: pray to God in his function as. Iswara; bang manifestation as Brahma; tang ज̆ํ: pray to God in his manifestation as

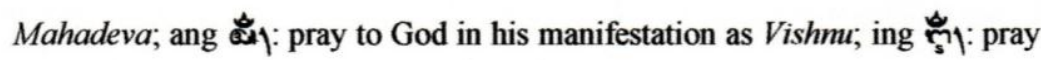
to God in his manifestation as Parama Shiva; nang ซึ/: pray to God in his manifestation as Maheswara, mang घ̆j: pray to God in his manifestation as

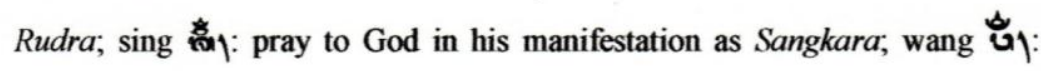
praying to God in his manifestation as Sambhu; dan yang $\stackrel{d}{\omega}$ : pray to God in his manifestation as Shiva Guru.

Regarding the Balinese script as a symbol of praying to God, the following can be seen in the data of the Balinese lontar usada manuscripts such as:
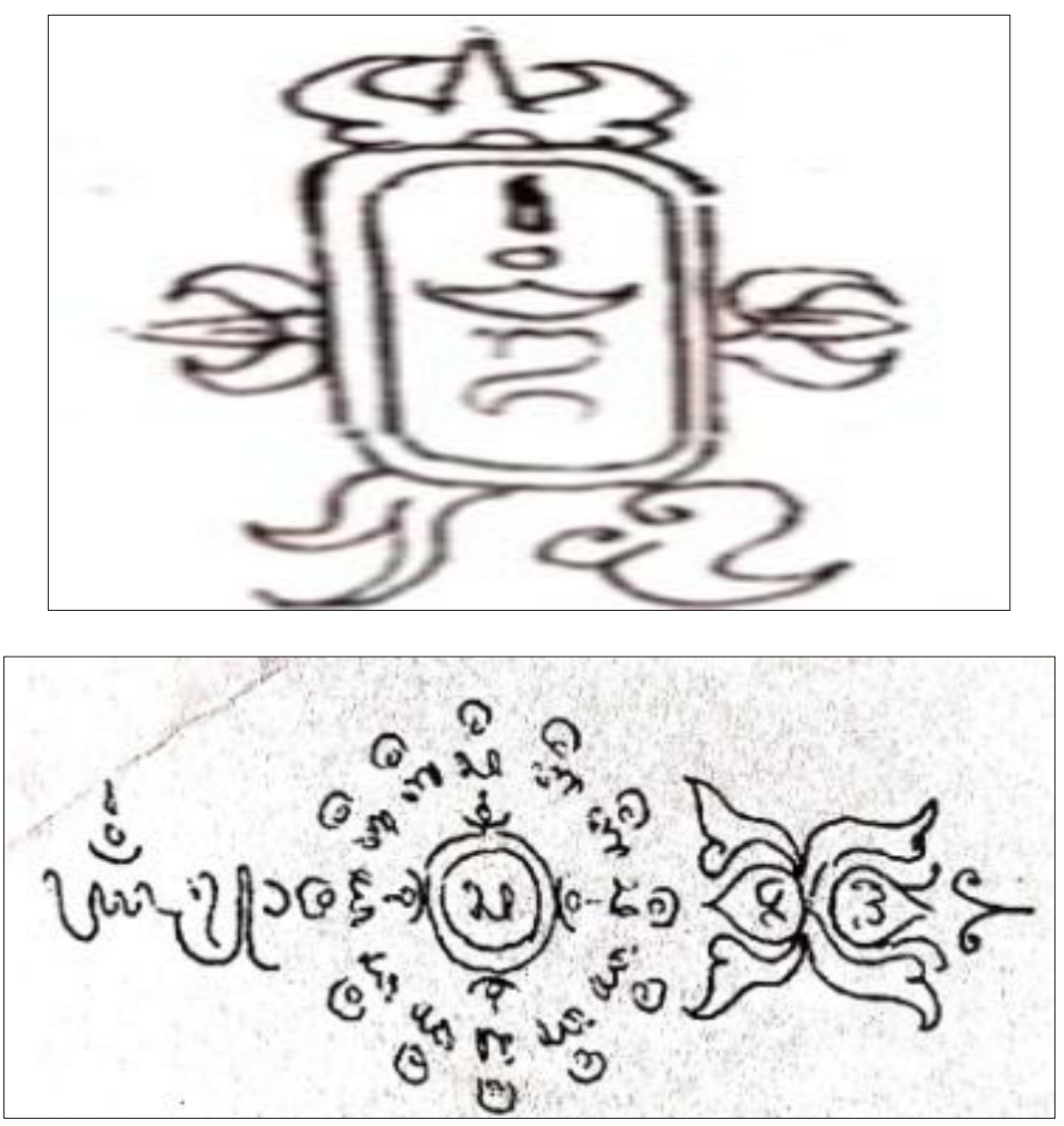

Figure 25. Usada Tiwas Punggung (Nala, 2006) 
As a symbol of invoking life energy

Balinese script, which is classified as a sacred script, which is ten in number, relates to ten sources of energy to get the energy that exists in the human body which is a gift from God that resides in the human body. The energy that exists in the human body is also called prana which is a gift from God with several other names such as: prana, apana, samana, udana, wyana. Likewise, specifically the energy or prana/bayu in the human body is called by the terms: naga, kemara, krakara, dewadatta, and dananjaya (Nala, 2006). All ten Balinese scripts correspond to the ten energies that exist in the human body with their place in the human organs can be emphasized as follows:

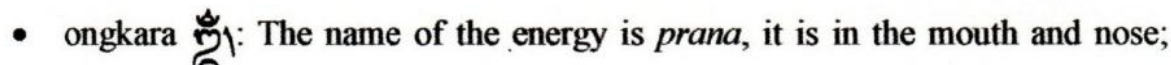

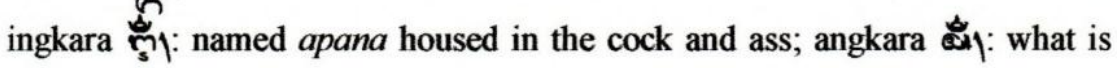
called a samana is located in the heart; ksangkara in crown; mangkara ध्रा: named wyana located in the joint; rangkara भ̆ named naga housed in fist; lungkara ウ̆j|: named kemara is located when the body vibrates; wangkara Ğj: named krakara place on the limbs when sneezing; yangkara ্ٌّ!: named Dewadatta is located in the respiratory organ ing; ingkara \&્山 dan aksara ungkara dananjaya which is located in the human organ at the center of the voice.

All Balinese scripts that are included in the dasa bayu script as explained above mean that people who are treated by traditional usada Balinese traditional healers can have life energy in the hope that they can return to health as usual. In the lontar usada script, the dasa bayu script in question can be seen in the rerajahan calligraphy image as follows:

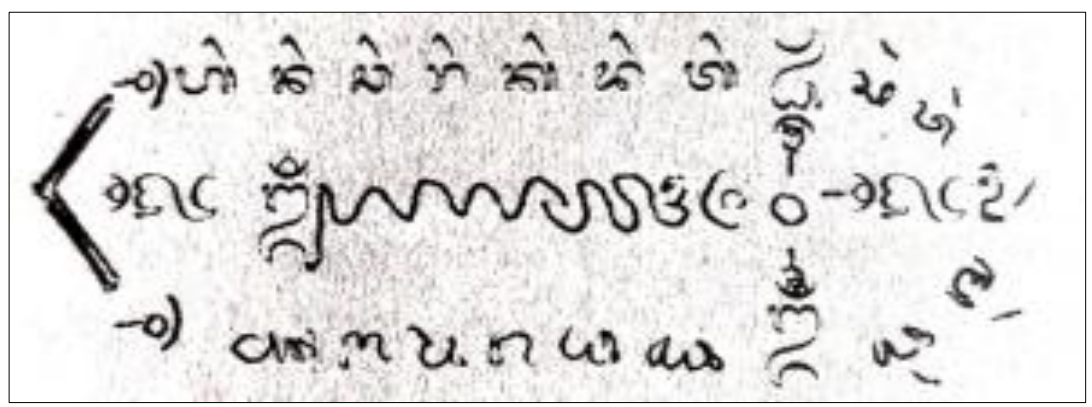

Figure 26. Usada Tiwas Punggung (Nala, 2006)

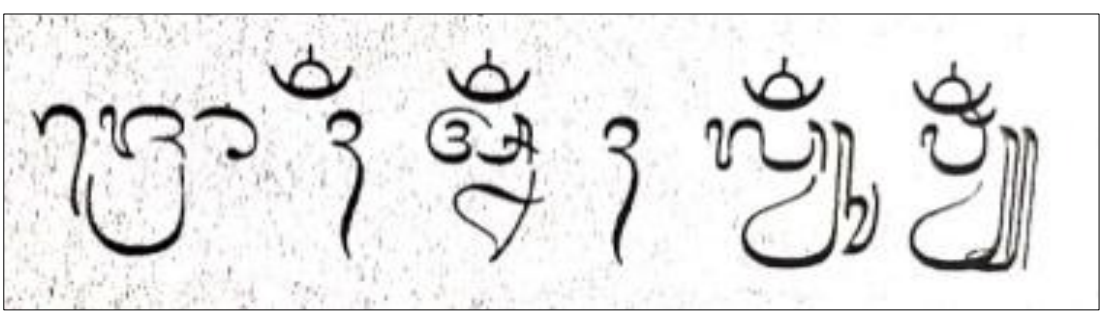

Figure 27. Usada Edan (Nala, 2006)

Suweta, I. M. (2021). Holy Bali scriptures in usada Bali traditional medicine. International Journal of Linguistics, Literature and Culture, 7(6), 441-458. https://doi.org/10.21744/ijllc.v7n6.1948 


\section{Symbol absorbing the magical power of life}

The existence of Balinese script as a sacred script in traditional Balinese usada medicine, in addition to placing God in its various manifestations, also means that the treatment performed by the shamans can be efficacious and can heal the people they treat. For the medicine he makes to be efficacious, it is indirectly expected by every traditional Balinese healer to make the medicines he mixes contain supernatural powers (religious magic), contain the sanctity of all infrastructure used as medicines. So, the traditional Balinese healers not only make real efforts by concocting various medicinal ingredients taken from the surrounding environment but also make an invisible effort through Balinese script which is classified as sacred and asks God in its various manifestations. In this regard, the following explains that there are several rerajahan calligraphy containing sacred Balinese script used in medicine by shamans who practice traditional Balinese medicines, namely:

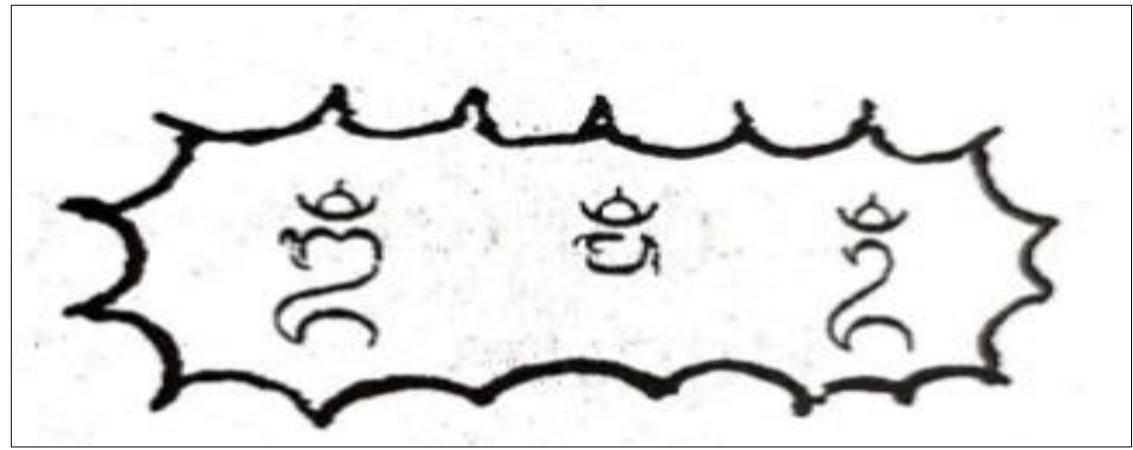

Figure 28. Usada Tiwas Punggung (Nala, 2006)

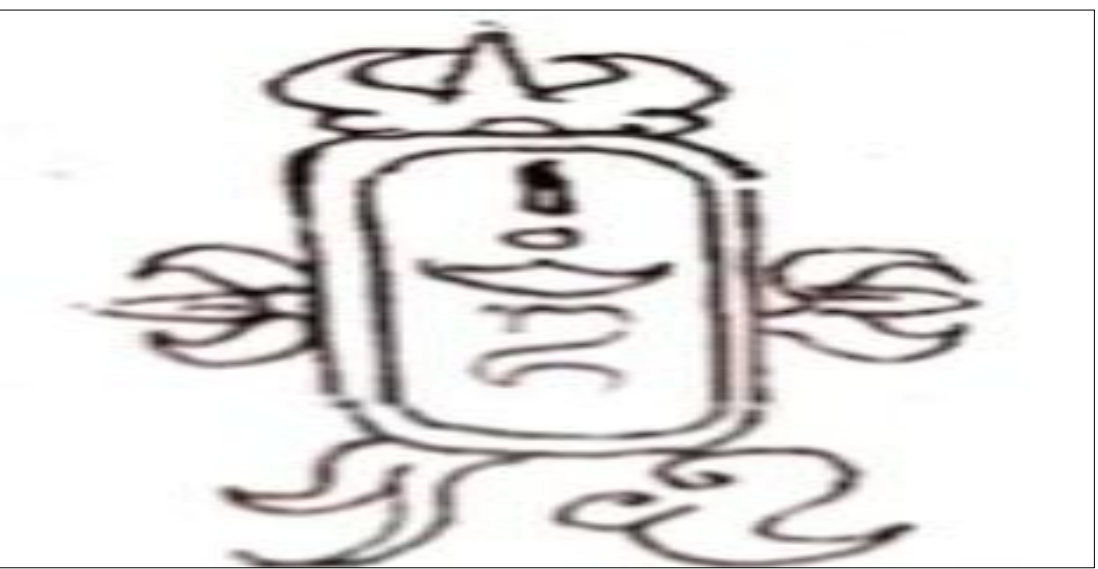

Figure 29. Usada Tiwas Punggung (Nala, 2006)

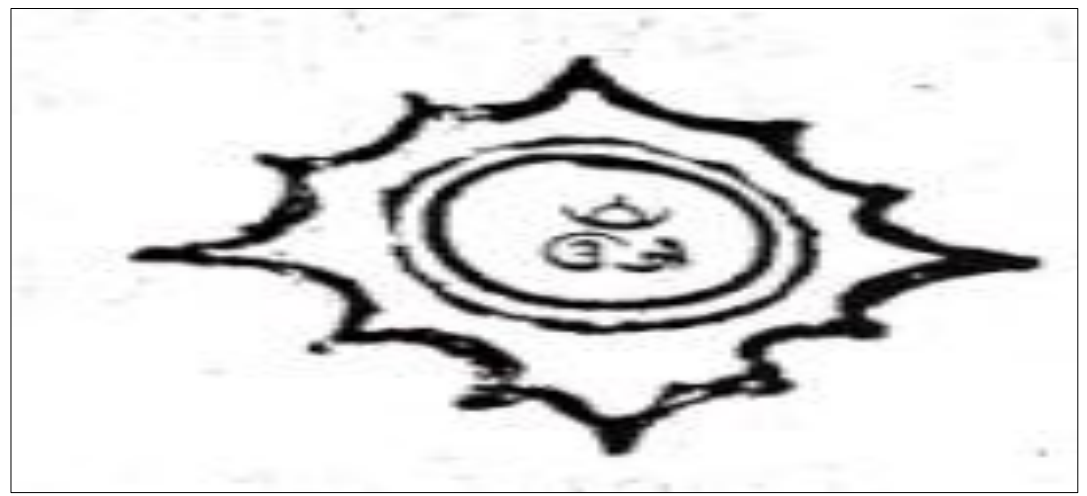

Figure 30. Usada Tiwas Punggung (Nala, 2006) 


\section{Conclusion}

Based on the discussion about the relationship between sacred Balinese script and the efforts of traditional Balinese healers to treat sick people so that they can become healthy, it can be briefly emphasized in the closing section of this paper as follows:

1) The forms of Balinese script used by traditional healers in usada Balinese medicine include scripts that are classified as: wijaksara script, modre script and wresastra/swalalita script with various script equipment as attributes.

2) The functions of Balinese script which are classified as sacred scripts used in traditional Balinese medicine are: as a symbol of God in its various manifestations, as a symbol of the universe, and as a member of the human body.

3) The meaning of the Balinese script used in traditional Balinese medicine is: praying to God in various holy powers of God, asking for life energy so that the person being treated can be healthy as before, can absorb magical religious energy so that medicine infrastructure is used to treat people Sickness has holy, efficacious, and contains powerful power to heal sick people to be healthy and recover as before.

Conflict of interest statement

The author declared that he have no competing interest.

Statement of authorship

The author has a responsibility for the conception and design of the study. The author has approved the final article.

Acknowledgments

I am grateful to two anonymous reviewers for their valuable comments on the earlier version of this paper. 


\section{References}

Alonso-Castro, A. J., Maldonado-Miranda, J. J., Zarate-Martinez, A., del Rosario Jacobo-Salcedo, M., FernándezGalicia, C., Figueroa-Zuñiga, L. A., ... \& Carranza-Alvarez, C. (2012). Medicinal plants used in the Huasteca Potosina, México. Journal of ethnopharmacology, 143(1), 292-298. https://doi.org/10.1016/j.jep.2012.06.035

Duranti, A. (2011). Linguistic anthropology: Language as a non-neutral medium. The Cambridge handbook of sociolinguistics, 28-46.

Eves, R., \& Kelly-Hanku, A. (2020). Medical pluralism, Pentecostal healing and contests over healing power in Papua New Guinea. Social Science \& Medicine, 266, 113381. https://doi.org/10.1016/j.socscimed.2020.113381

Foley, R. (2011). Performing health in place: The holy well as a therapeutic assemblage. Health \& place, 17(2), 470479. https://doi.org/10.1016/j.healthplace.2010.11.014

Foley, W. A. (1997). Anthropological linguistics: An introduction. Wiley-Blackwell.

Halliday, M. A. K., \& Hasan, R. (1989). Language, context, and text: Aspects of language in a social-semiotic perspective.

Jendra, W. dkk. 1975. Sebuah Deskripsi tentang Latar Belakang Sosial Budaya Bahasa Bali. Denpasar. Proyek Penelitian Bahasa dan Sastra Indonesia dan Daerah, Pusat Pembinaan dan Pengembangan Bahasa, Departemen Pendidikan dan Kebudayaan.

Kardji, I. W. (1999). Ilmu hitam dari Bali. Bali Media Adhikarsa.

Lindeman, M., \& Aarnio, K. (2007). Superstitious, magical, and paranormal beliefs: An integrative model. Journal of research in personality, 41(4), 731-744. https://doi.org/10.1016/j.jrp.2006.06.009

McCauley, A. P. (1988). Healing texts and healing techniques in indigenous Balinese medicine. Social Science \& Medicine, 27(8), 779-787. https://doi.org/10.1016/0277-9536(88)90230-4

Nala, N. (2006). Aksara Bali dalam usada. Pāramita.

Palmer, G. B. (1996). Toward a theory of cultural linguistics. University of Texas Press.

Preston, J., \& Epley, N. (2009). Science and God: An automatic opposition between ultimate explanations. Journal of Experimental Social Psychology, 45(1), 238-241. https://doi.org/10.1016/j.jesp.2008.07.013

Pulasari, J. M. (2009). Nawa Usadha Bali. Pāramita.

Suastika, I. M. (2005). Keberaksaraan dalam Kebudayaan (Literacy in Culture). Denpasar: Masters and Doctoral Study Program in Cultural Studies, Udayana University.

Sujarwo, W., Keim, A. P., Caneva, G., Toniolo, C., \& Nicoletti, M. (2016). Ethnobotanical uses of neem (Azadirachta indica A. Juss.; Meliaceae) leaves in Bali (Indonesia) and the Indian subcontinent in relation with historical background and phytochemical properties. Journal of Ethnopharmacology, 189, 186-193. https://doi.org/10.1016/j.jep.2016.05.014

Sujarwo, W., Keim, A. P., Savo, V., Guarrera, P. M., \& Caneva, G. (2015). Ethnobotanical study of Loloh: Traditional herbal drinks from Bali (Indonesia). Journal of Ethnopharmacology, 169, 34-48. https://doi.org/10.1016/j.jep.2015.03.079

Suryani, N. G. A. P., Gelgel, I. P., \& Dharmika, I. B. (2020). Non-Medical Medicine Culture on Siwa Murti Bali School. International Journal of Linguistics, Literature and Culture, 6(5), 21-30.

Unterrainer, H. F., Huber, H. P., Sorgo, I. M., Collicutt, J., \& Fink, A. (2011). Dimensions of religious/spiritual wellbeing and schizotypal personality. Personality and Individual Differences, 51(3), 360-364. https://doi.org/10.1016/j.paid.2011.04.007

UPTD BPOT KOM team. 2008. Kumpulan Usada I (Usadha I Association). Denpasar: Pusdok Bali

Williams, A. (2016). Spiritual landscapes of Pentecostal worship, belief, and embodiment in a therapeutic community: New critical perspectives. Emotion, Space and Society, 19, 45-55. https://doi.org/10.1016/j.emospa.2015.12.001

Yudhiantara, K. (2003). Rahasya Pemujaan Sakti Durga Bhairawi Meditasi, Mantra dan Hakekat Devi Dasa Mahavidya. Surabaya: Paramita. 